\title{
L-lactic acid production from D-xylose with Candida sonorensis expressing a heterologous lactate dehydrogenase encoding gene
}

Kari T Koivuranta ${ }^{1 *}$, Marja Ilmén ${ }^{1}$, Marilyn G Wiebe ${ }^{1}$, Laura Ruohonen ${ }^{1}$, Pirkko Suominen $^{2}$ and Merja Penttilä ${ }^{1}$

\begin{abstract}
Background: Bioplastics, like polylactic acid (PLA), are renewable alternatives for petroleum-based plastics. Lactic acid, the monomer of PLA, has traditionally been produced biotechnologically with bacteria. With genetic engineering, yeast have the potential to replace bacteria in biotechnological lactic acid production, with the benefits of being acid tolerant and having simple nutritional requirements. Lactate dehydrogenase genes have been introduced to various yeast to demonstrate this potential. Importantly, an industrial lactic acid producing process utilising yeast has already been implemented. Utilisation of D-xylose in addition to D-glucose in production of biochemicals such as lactic acid by microbial fermentation would be beneficial, as it would allow lignocellulosic raw materials to be utilised in the production processes.

Results: The yeast Candida sonorensis, which naturally metabolises D-xylose, was genetically modified to produce L-lactic acid from D-xylose by integrating the gene encoding L-lactic acid dehydrogenase (IdhL) from Lactobacillus helveticus into its genome. In microaerobic, $\mathrm{CaCO}_{3}$-buffered conditions a C. sonorensis IdhL transformant having two copies of the $/ \mathrm{dh} L$ gene produced $31 \mathrm{~g} \mathrm{I}^{-1}$ lactic acid from $50 \mathrm{~g} \mathrm{I}^{-1}$ D-xylose free of ethanol.

Anaerobic production of lactic acid from D-xylose was assessed after introducing an alternative pathway of D-xylose metabolism, i.e. by adding a xylose isomerase encoded by XYLA from Piromyces sp. alone or together with the xylulokinase encoding gene XKS1 from Saccharomyces cerevisiae. Strains were further modified by deletion of the endogenous xylose reductase encoding gene, alone or together with the xylitol dehydrogenase encoding gene. Strains of $C$. sonorensis expressing xylose isomerase produced L-lactic acid from D-xylose in anaerobic conditions. The highest anaerobic L-lactic acid production $\left(8.5 \mathrm{~g} \mathrm{I}^{-1}\right)$ was observed in strains in which both the xylose reductase and xylitol dehydrogenase encoding genes had been deleted and the xylulokinase encoding gene from S. cerevisiae was overexpressed.

Conclusions: Integration of two copies of the IdhL gene in C. sonorensis was sufficient to obtain good L-lactic acid production from D-xylose. Under anaerobic conditions, the $/ \mathrm{dh} L$ strain with exogenous xylose isomerase and xylulokinase genes expressed and the endogenous xylose reductase and xylitol dehydrogenase genes deleted had the highest $\mathrm{L}$ - lactic acid production.
\end{abstract}

Keywords: Candida sonorensis, Yeast, D-xylose, L-lactic acid production, Xylose isomerase, Pyruvate decarboxylase, Xylose reductase, Xylitol dehydrogenase

\footnotetext{
*Correspondence: kari.koivuranta@vtt.fi

${ }^{1}$ VTT Technical Research Centre of Finland, P. O. Box 1000, Espoo Fl-02044 VTT, Finland

Full list of author information is available at the end of the article
}

\section{Biomed Central}

(c) 2014 Koivuranta et al.; licensee BioMed Central Ltd. This is an Open Access article distributed under the terms of the Creative Commons Attribution License (http://creativecommons.org/licenses/by/4.0), which permits unrestricted use, distribution, and reproduction in any medium, provided the original work is properly credited. The Creative Commons Public Domain Dedication waiver (http://creativecommons.org/publicdomain/zero/1.0/) applies to the data made available in this article, unless otherwise stated. 


\section{Background}

Lactic acid and its derivatives, e.g. biodegradable polymers, are widely used in food, chemical, cosmetic and pharmaceutical industries [1]. Today, L-lactic acid is commercially manufactured predominantly by bacterial fermentation. However, the bacterial process has both nutritional (complex medium) and $\mathrm{pH}$ (neutral $\mathrm{pH}$ ) requirements which increase the cost of the process [1,2]. To improve the economics of the process, use of yeast for L-lactic acid production instead of bacteria has already been implemented by Cargill Inc [3]. Producing L-lactic acid with yeast enables the use of cheaper growth media and low $\mathrm{pH}$ cultures, the latter allowing down-stream recovery of L-lactic acid without producing as much gypsum waste as at high $\mathrm{pH}[2,4]$. Production of L-lactic acid from D-glucose has been described with several yeast species, e.g. Saccharomyces cerevisiae, Kluyveromyces lactis, Scheffersomyces stipitis and Candida sonorensis, expressing L-lactate dehydrogenase encoding genes originating from different organisms [4-6].

Cheap growth media could include sugars derived from hydrolysed plant biomass which contains in addition to hexoses (e.g. D-glucose), significant amounts of pentoses (e.g. D-xylose) [7]. To achieve cost-effective bioprocesses based on plant biomass both hexoses and pentoses need to be consumed and converted to the desired product by the process organism. Production of L-lactic acid from Dxylose or D-xylose-containing raw materials has been shown with several bacterial species [5]. In eukaryotes, Dxylose-derived L-lactic acid production has been reported with the filamentous fungus Rhizopus oryzae [8-10] and with the genetically modified yeast species $S$. stipitis and Candida utilis expressing the $L D H$ genes of Lactobacillus helveticus and Bos taurus, respectively $[11,12]$.

$\mathrm{D}$-xylose can be converted to D-xylulose, and further to pyruvate, via the oxidoreductive xylose reductase xylitol dehydrogenase pathway. D-Xylose is first reduced to xylitol with a NAD(P)H-dependent xylose reductase (XR encoded by $X Y L 1$ ), and xylitol further oxidised to $\mathrm{D}$-xylulose with a $\mathrm{NAD}^{+}$-dependent xylitol dehydrogenase (XDH encoded by XYL2) [13]. S. stipitis like Pachysolen tannophilus and Candida shehatae can convert $\mathrm{D}$-xylose to ethanol under aerobic or oxygen-limited conditions [14]. The ability of these three yeast species to ferment $\mathrm{D}$-xylose under oxygen-limited conditions most likely reflects the fact that they each possess a xylose reductase with dual cofactor specificity (NADH and $\mathrm{NADPH}$ ), whereas fungal species incapable of D-xylose fermentation have strictly NADPH-dependent xylose reductases. Without the dual cofactor specificity of xylose reductase, the overall redox neutral conversion of Dxylose to D-xylulose by xylose reductase and xylitol dehydrogenase results in a redox cofactor imbalance $[13,14]$. The xylose reductase and xylitol dehydrogenase encoding genes from $S$. stipitis have been expressed in $S$. cerevisiae, which lacks a functional endogenous Dxylose pathway, to construct D-xylose-fermenting, ethanolproducing strains $[13,14]$.

The D-xylose utilisation pathway common in bacteria involves xylose isomerase, which directly isomerises Dxylose to D-xylulose without any cofactors. Thus, a strategy for avoiding redox imbalance during $\mathrm{D}$-xylose metabolism in yeast is the introduction of a xylose isomerase encoding gene of bacterial [15-18] or fungal $[19,20]$ origin. However, only some xylose isomerases have been shown to be functional in yeast; e.g. the bacterial xylose isomerases of Thermus thermophilus [21], Escherichia coli [16,22], Streptomyces coelicolor [16], Clostridium phytofermentans [17] and Bacteroides stercoris [18] and most importantly, the eukaryotic xylose isomerases from the anaerobic cellulolytic fungi Piromyces sp E2 [19] and Orpinomyces [20].

Bacterial genes encoding a xylose isomerase have also been expressed in yeast species which have an endogenous pathway of D-xylose metabolism to enhance ethanol production. Overexpression of the E. coli xylose isomerase encoding gene in Schizosaccharomyces pombe resulted in ethanol production, which was not seen with the wild type strain [22]. Overexpression of E. coli or $S$. coelicolor xylose isomerase encoding genes in a Hansenula polymorpha strain from which the xylose reductase encoding gene had been deleted resulted in ethanol production comparable to the native $H$. polymorpha host, even though the xylose isomerase activity was only $20 \%$ of that present in the bacterial host strains [16].

In the present study we used a Candida sonorensis strain expressing the L. helveticus ldhL gene to assess Llactic acid production from D-xylose. This yeast has been shown to produce L-lactic acid from D-glucose at low $\mathrm{pH}$ [6]. In addition to lactic acid production with the endogenous xylose reductase - xylitol dehydrogenase pathway we demonstrate for the first time lactic acid production via the xylose isomerase pathway in yeast. We present data on enhanced anaerobic L-lactic acid production by a $C$. sonorensis $l d h L$ strain by the expression of Piromyces XYLA alone or with S. cerevisiae XKS1 in strains (i) with an intact endogenous D-xylose pathway and (ii) in which the xylose reductase encoding gene alone or in combination with the xylitol dehydrogenase encoding gene has been deleted.

\section{Results}

\section{L-lactic acid production from D-xylose by a Candida sonorensis IdhL strain}

To assess L-lactic acid production from D-xylose the wild type and transformant C29, with one copy of $l d h L$, were cultivated in buffered D-xylose $\left(50 \mathrm{~g} \mathrm{l}^{-1}\right)$ medium (YXC) in microaerobic conditions. During the $168 \mathrm{~h}$ cultivation, the biomass of the C29 transformant and wild 
type increased from $\mathrm{OD}_{600} 10$ to $26( \pm 1.7)$ and $19( \pm 2.2)$, respectively. C29 consumed all D-xylose provided, whereas the wild type strain did not; $9.2 \pm 2.9$ g residual D-xylose $1^{-1}$ was observed at the end of the cultivation with the wild type. No L-lactic acid was produced by the wild type strain, which produced $7.8 \pm 1.1$ g xylitol $\mathrm{l}^{-1}$, $4.0 \pm 0.9 \mathrm{~g}$ ethanol $\mathrm{l}^{-1}$ and $6.5 \pm 0.9 \mathrm{~g}_{\text {acetate }} \mathrm{l}^{-1}$ (Table 1 ). The C29 transformant produced $26.7 \pm 0.8 \mathrm{~g}$ L-lactic acid $\mathrm{l}^{-1}$ with a yield of $0.53 \pm 0.03$ ( $\mathrm{g}$ L-lactic acid per $\mathrm{g}$ D-xylose consumed). Neither ethanol nor acetate was produced by $\mathrm{C} 29$, but some $\mathrm{D}$-xylose was reduced to xylitol $\left(4.6 \pm 0.5 \mathrm{~g} \mathrm{l}^{-1}\right)$, all of which was consumed before the end of the cultivation.

\section{Pre-cultivation on D-xylose improved L-lactic acid production by the Candida sonorensis IdhL strain}

In the preliminary cultivations the biomass of $l d h L$ transformants was generated either on D-glucose or Dxylose. After transfer of the biomass to buffered Dxylose (50 $\mathrm{g} \mathrm{l}^{-1}$ ) medium (YXC), lower production of L-lactic acid was observed in cultures inoculated with D-glucose-grown cells than in cultures inoculated with D-xylose-grown cells (data not shown). In addition, when C169 (PDC-, 2*ldhL; see below) was pre-cultured on either D-glucose (YGM) or D-xylose (YXM) to obtain biomass for a cultivation in buffered D-glucose $\left(30 \mathrm{~g} \mathrm{l}^{-1}\right)$ and D-xylose (30 $\mathrm{g} \mathrm{l}^{-1}$ ) medium (YGXC) (Figure 1), the cultures inoculated with D-glucose-grown cells consumed D-glucose faster $\left(2.6 \mathrm{~g} \mathrm{l}^{-1} \mathrm{~h}^{-1} ; \mathrm{p}<0.05\right)$ than the culture inoculated with D-xylose-grown cells $\left(1.7 \mathrm{~g} \mathrm{l}^{-1} \mathrm{~h}^{-1}\right)$, while consuming D-xylose more slowly $(0.54 \pm 0.01$ and $0.60 \pm$ $0.00 \mathrm{~g} \mathrm{l}^{-1} \mathrm{~h}^{-1}$, for cultures inoculated with D-glucose- and D-xylose-grown cells, respectively).

Cultures inoculated with D-xylose-grown cells produced more L-lactic acid (37 $\left.\pm 0.2 \mathrm{~g} \mathrm{l}^{-1} ; \mathrm{p}<0.05\right)$ and less xylitol $\left(1.9 \pm 0.1 \mathrm{~g} \mathrm{l}^{-1}\right)$ than cultures inoculated with $\mathrm{D}$ glucose-grown cells $\left(28 \pm 0.1 \mathrm{~g} \mathrm{l}^{-1} \mathrm{~L}\right.$-lactic acid and $11.6 \pm$ $0.2 \mathrm{~g} \mathrm{l}^{-1}$ xylitol). Most of the L-lactic acid was produced from D-glucose when cultures were inoculated with Dglucose-grown cells, whereas approximately $12 \mathrm{~g} \mathrm{l}^{-1} \mathrm{~L}$ lactic acid (out of the total $37 \mathrm{~g} \mathrm{l}^{-1}$ ) was produced from $\mathrm{D}$-xylose after $\mathrm{D}$-glucose had been consumed in cultures inoculated with D-xylose-grown cells (Figure 1A).
Additionally, the xylitol produced was subsequently consumed in the cultures inoculated with D-xylosegrown cells, but not in the cultures inoculated with Dglucose-grown cells.

\section{Pre-cultivation on D-xylose increased the activities of} xylose reductase, xylitol dehydrogenase and xylulokinase as well as mRNA levels of the corresponding genes in the C. sonorensis IdhL strain

Xylose reductase, xylitol dehydrogenase and xylulokinase activities were assayed from the C169 cells after $27 \mathrm{~h}$ of cultivation on D-xylose, after inoculation with either Dglucose- or D-xylose-grown cells. The NADPH-dependent xylose reductase activity per mg protein was 130 and $270 \mathrm{mU}$ in cultures inoculated with D-glucose- and Dxylose-grown cells, respectively (Figure 1B). No NADHdependent xylose reductase activity was detected. The xylitol dehydrogenase activities were 60 and $940 \mathrm{mU} / \mathrm{mg}$ protein and xylulokinase activities 50 and $150 \mathrm{mU} / \mathrm{mg}$ protein in cultures inoculated with D-glucose- or Dxylose-grown precultures, respectively.

A Northern analysis was carried out to analyse the mRNA levels of genes encoding xylose reductase (XYL1), xylitol dehydrogenase (XYL2) and xylulokinase (XKS1) in the D-glucose- and D-xylose-grown C169 cells. The XYL1, $X Y L 2$ and $X K S 1$ genes had 3-, 5- and 3-fold higher mRNA levels in cells grown on D-xylose compared to cells grown on D-glucose (Figure 2). Comparable differences in the mRNA levels of XYL1, XYL2 and XKS1 in D-glucose- and $\mathrm{D}$-xylose-grown cells were seen also in the wild type $C$. sonorensis strain (data not shown).

\section{Effect of PDC deletion and copy number of the $I d h L$ gene on L-lactic acid production}

Several C. sonorensis transformants with one to three copies of $l d h L$ integrated in the genome, and one or both of the PDC genes deleted were previously constructed and characterised for L-lactic acid production on D-glucose [6]. To analyse the effect of deletion of both PDC1 and PDC2 (C184) on L-lactic acid production from D-xylose, strains with one copy of $l d h L$, with (C29) or without (C184) intact PDC genes, were cultivated in buffered D-xylose $\left(50 \mathrm{~g} \mathrm{l}^{-1}\right)$ medium $(\mathrm{YXC})$ in

Table 1 Maximum L-lactic acid and xylitol production in microaerobic cultivation

\begin{tabular}{|c|c|c|c|c|}
\hline Strain & Genotype & L-lactic acid ( $\mathrm{g} \mathrm{I}^{-1}$ ) & L-lactic acid yield $\left(\mathrm{g} \mathrm{g}^{-1}\right)$ & Xylitol $\left(\mathrm{g} \mathrm{I}^{-1}\right)$ \\
\hline Wild type $^{1}$ & & n.d. & n.d. & $7.8 \pm 1.1^{*}$ \\
\hline C29 & $x:: 1 d h L$ & $26.7 \pm 0.8$ & $0.53 \pm 0.03$ & $4.6 \pm 0.5$ \\
\hline C184 & $p d c 1 \Delta:: / d h L p d c 2 \Delta$ & $27.3 \pm 0.8$ & $0.53 \pm 0.02$ & $3.9 \pm 0.7$ \\
\hline C169 & $p d c 1 \Delta:: / d h L$ pdc2 $\Delta \because: / d h L$ & $30.8 \pm 1.0^{*}$ & $0.57 \pm 0.03$ & $5.6 \pm 0.5$ \\
\hline
\end{tabular}

${ }^{1}$ The wild type strain also produced $4.0 \pm 0.9 \mathrm{~g}$ ethanol $\mathrm{I}^{-1}$ and $6.5 \pm 0.9 \mathrm{~g}$ acetate $\mathrm{I}^{-1}$.

Maximum concentrations of L-lactic acid and xylitol produced from D-xylose by C. sonorensis wild type and C29, C169 and C184, and yield of L-lactic acid from D-xylose. Cells were cultivated in buffered YNB medium with $50 \mathrm{~g} \mathrm{I}^{-1} \mathrm{D}$-xylose medium at $30^{\circ} \mathrm{C}, 100 \mathrm{rpm}$. Data are mean \pm sem from 3 to 12 replicate cultures. n.d. $=$ not detected. An asterisk indicates that the value is significantly different $(p<0.05)$ from other values in the same column. 

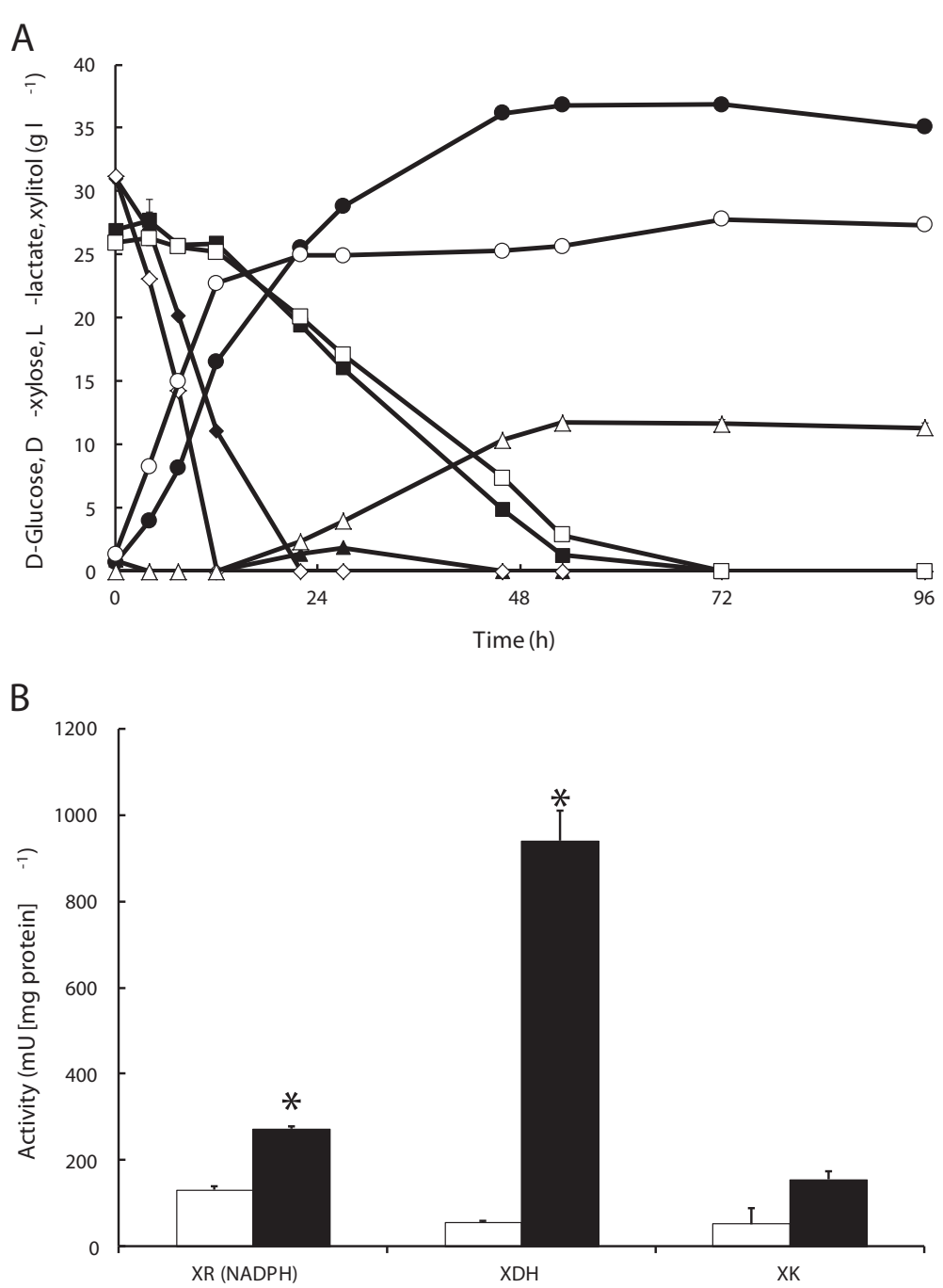

Figure $1 \mathrm{D}$-Glucose and D-xylose consumption and xylitol and L-lactic acid production in buffered microaerobic cultivation.

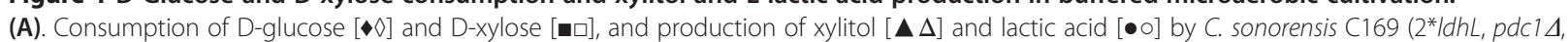
pdc2 $\Delta$ ) in $\mathrm{CaCO}_{3}$-buffered YNB with $30 \mathrm{~g} \mathrm{I}^{-1}$ D-glucose and $30 \mathrm{~g} \mathrm{I}^{-1}$ D-xylose at $30^{\circ} \mathrm{C}, 100 \mathrm{rpm}$. Cultures were inoculated with cells which had been pre-cultured on D-xylose (closed symbols) or D-glucose (open symbols). (B). Xylose reductase (XR, NADPH-dependent), xylitol dehydrogenase $(\mathrm{XDH})$ and xylulokinase (XK) activities assayed after $27 \mathrm{~h}$ of cultivation in $\mathrm{CaCO}_{3}$-buffered YNB with $30 \mathrm{~g} \mathrm{I}^{-1} \mathrm{D}$-glucose and $30 \mathrm{~g} \mathrm{I}^{-1} \mathrm{D}$-xylose. Cultures were inoculated with D-xylose (black bars) or D-glucose (white bars) grown cells. Results are averages \pm sem from duplicate flask cultivations. Where error bars are not visible they were smaller than the symbol. An asterisk indicates that the value is significantly different $(p<0.05)$ from that of the cultures inoculated with D-glucose-grown cells.

microaerobic conditions (Table 1). Both strains produced $27 \mathrm{~g}$ L-lactic acid $\mathrm{l}^{-1}$ during the 168 hours cultivation. Additionally, C29 and C184 produced similar amounts of xylitol (4.6 $\pm 0.5 \mathrm{~g} \mathrm{l}^{-1}$ and $3.9 \pm 0.7 \mathrm{~g} \mathrm{l}^{-1}$, respectively) during the cultivation, and both strains consumed all the xylitol by the end of the cultivation. Both strains produced similar amounts of biomass, and neither of the strains produced ethanol or acetate under the conditions studied.

To test the effect of the number of copies of the $l d h L$ gene on L-lactic acid production from D-xylose, C169 was cultivated in the same conditions as C29 and C184
(Table 1). This pdc1- strain, with two copies of $l d h L$, produced slightly more L-lactic acid $\left(30.8 \pm 1.0 \mathrm{~g} \mathrm{l}^{-1}\right.$; $\mathrm{p}<0.05)$ than the single copy strains $(\mathrm{C} 29$ and $\mathrm{C} 184$, Table 1). C169 also produced slightly more xylitol (5.6 \pm $0.5 \mathrm{~g} \mathrm{l}^{-1}$; t-test $\mathrm{p}<0.05$, ANOVA $\left.\mathrm{p}>0.05\right)$ than $\mathrm{C} 184$. Xylitol was consumed by both strains by the end of the cultivation. $\mathrm{C} 169$ produced less biomass $\left(\mathrm{OD}_{600} 22\right)$ than C184 (OD 600 26).

In non-buffered conditions, i.e. lacking $\mathrm{CaCO}_{3}, C$. sonorensis C169 (2 copies of ldhL) and C184 (1 copy $l d h L$ ) both produced approximately $13 \mathrm{~g} \mathrm{l}^{-1} \mathrm{~L}$-lactic acid from $24 \mathrm{~g} \mathrm{l}^{-1} \mathrm{D}$-xylose (yield $\sim 0.5 \mathrm{~g} \mathrm{~g}^{-1}$ ). L-Lactic acid 


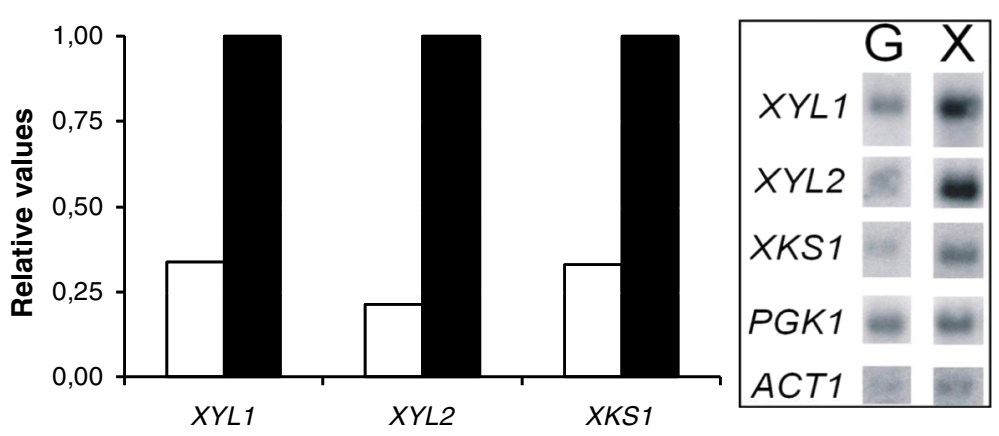

Figure 2 Northern analysis of mRNA levels of $X Y L 1, X Y L 2$ and $X K S 1$ in C. sonorensis C169. RNA was isolated from cultures grown for $20 \mathrm{~h}$ on YNB medium containing $50 \mathrm{~g} \mathrm{I}^{-1}$ D-glucose (G, white bars) or D-xylose (X, black bars). The left panel shows relative gene expression, with the expression level in cells growing on D-xylose $=1$ of the hybridisation signals shown in the right panel. C. sonorensis XYL1, XYL2, XKS1 and PGK1 and S. cerevisiae ACT1 genes were used as probes. The hybridisation signals were normalized to total RNA.

production and D-xylose consumption stopped after 41 hours when the $\mathrm{pH}$ had decreased from 5.4 to 2.8 (data not shown).

\section{L-lactic acid production from D-xylose by a C. sonorensis IdhL strain expressing Piromyces sp. XYLA and S. cerevisiae XKS1 genes}

To verify the functional expression of the Piromyces sp. E2 $X Y L A$ gene encoding xylose isomerase $(X Y L A)$ in $C$. sonorensis, $X Y L A$ was expressed alone or together with the $S$. cerevisiae XKS1 gene encoding xylulokinase (ScXKS1) in a $C$. sonorensis strain carrying one copy of the $l d h L$ gene. Strains with $l d h L$ (C29), ldhL with XYLA (C281) or $l d h L$ with XYLA and ScXKS1 (C282-C284) were cultivated in $\mathrm{CaCO}_{3}$-buffered YP medium with $50 \mathrm{~g} \mathrm{l}^{-1} \mathrm{D}$-xylose. Xylose isomerase activity $\left(100 \mathrm{mU} \mathrm{mg}^{-1}\right)$ was measurable after $24 \mathrm{~h}$ cultivation, indicating that the $X Y L A$ encoded enzyme was functionally expressed in C. sonorensis (Table 2). C281 and C282-C284 consumed D-xylose at a higher $(\mathrm{p}<0.05)$ rate $\left(0.48 \pm 0.01 \mathrm{~g} \mathrm{D}\right.$-xylose $\left.\mathrm{l}^{-1} \mathrm{~h}^{-1}\right)$ than $\mathrm{C} 29(0.43 \pm 0.00 \mathrm{~g}$ D-xylose $\mathrm{l}^{-1} \mathrm{~h}^{-1}$ ) and produced slightly more biomass. C282-C284 produced less xylitol $\left(6.7 \pm 0.2 \mathrm{~g} \mathrm{l}^{-1}\right)$ than C29 $\left(8.1 \pm 0.3 \mathrm{~g} \mathrm{l}^{-1}\right)$ or C281 $\left(8.7 \pm 0.2 \mathrm{~g} \mathrm{l}^{-1}\right.$; Table 3$)$. Xylitol was consumed before the end of the cultivation. These strains produced similar amounts of L-lactic acid $\left(31 \mathrm{~g} \mathrm{l}^{-1}\right)$

Table 2 Xylose isomerase activity

\begin{tabular}{lll}
\hline Strain & Genotype & XI activity $\left(\mathbf{m U ~} \mathbf{~ g}^{-\mathbf{1}}\right)$ \\
\hline C29 & IdhL & $10 \pm 0$ \\
C281 & IdhL, XYLA & $110 \pm 10$ \\
C282-C284 & IdhL, XYLA, SCXKS1 & $90 \pm 10$ \\
\hline
\end{tabular}

Xylose isomerase (XI) activity in C. sonorensis C29 containing IdhL, and in IdhL strains expressing the Piromyces sp. XYLA gene alone (C281) or with the $S$. cerevisiae XKS1 gene (C282-C284). The activity was measured from cell free extracts prepared after overnight cultivation of cells in YP with $50 \mathrm{~g} \mathrm{I}^{-1} \mathrm{D}$-glucose and $10 \mathrm{mM} \mathrm{MgCl}$. The activity values are means \pm sem from $3(\mathrm{C} 29, \mathrm{C} 281)$ or 6 (C282-C284, duplicates of three independent transformants) aerobic flask cultivations. at similar rates $\left(0.27 \pm 0.01 \mathrm{~g} \mathrm{l}^{-1} \mathrm{~h}^{-1}\right.$ for C29, $0.26 \pm$ $0.01 \mathrm{~g} \mathrm{l}^{-1} \mathrm{~h}^{-1}$ for C281 and $0.29 \pm 0.00 \mathrm{~g} \mathrm{l}^{-1} \mathrm{~h}^{-1}$ for C282C284). The strain with only XYLA (C281) accumulated more D-xylulose $\left(0.63 \mathrm{~g} \mathrm{l}^{-1}\right)$ than either the control (C29,

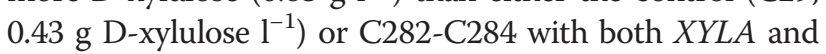
ScXKS1 (0.45 g D-xylulose $\left.1^{-1}\right)$.

\section{Identification of xylose reductase and xylitol}

\section{dehydrogenase encoding genes from $C$. sonorensis}

In order to study the functionality of the XYLA pathway in the absence of the endogenous oxido-reductive Dxylose pathway the XYL1 and XYL2 genes were cloned and deleted.

The xylose reductase homologue $X Y L 1$ isolated from the genomic library of $C$. sonorensis contains a protein coding region of $960 \mathrm{bp}$. The predicted amino acid sequence of XYL1 (319 aa) had 76\% overall identity with known fungal xylose reductases (data not shown). Southern analysis at low stringency detected only the XYL1 gene. $X Y L 1$ was confirmed to code for a xylose reductase in XYL1 deletion strains (C689 and C690), which did not grow on D-xylose (data not shown) and had no detectable xylose reductase activity (Table 4).

The xylitol dehydrogenase homologue $X Y L 2$ contains a 1065 bp protein coding region. The deduced amino acid sequence had at most $74 \%$ identity with known fungal xylitol dehydrogenases (data not shown). Southern analysis at low stringency detected some other weakly hybridising genomic fragments in addition to XYL2. XYL2 was characterised as a xylitol dehydrogenase encoding gene by deleting it from the wild type $C$. sonorensis strain. The XYL2 deletion strains (C684, C685 and C686) grew slower on D-xylose (data not shown) and had only $\sim 20 \%$ of xylitol dehydrogenase activity compared to the wild type $(126 \pm 4 \mathrm{mU} / \mathrm{mg}$ and $571 \pm 21 \mathrm{mU} / \mathrm{mg}$, respectively) (Table 4). 
Table 3 L-lactic acid, xylitol and D-xylulose production with XYLA strains in microaerobic cultivation

\begin{tabular}{lllll}
\hline Strains & L-lactic acid $\left(\mathbf{g ~ I}^{-\mathbf{1}}\right)$ & L-lactic acid yield $\left(\mathbf{g ~ g ~}^{\mathbf{- 1}}\right)$ & Xylitol $\mathbf{( g ~ ~ ^ { - \mathbf { 1 } } )}$ & D-Xylulose $\mathbf{( g ~ ~ ^ { - 1 } )}$ \\
\hline C29 & $31.0 \pm 0.3$ & $0.59 \pm 0.01$ & $8.1 \pm 0.3^{*}$ & $0.43 \pm 0.01$ \\
C281 & $30.9 \pm 0.3$ & $0.60 \pm 0.01$ & $8.7 \pm 0.2^{*}$ & $0.63 \pm 0.02^{*}$ \\
C282-C284 & $31.8 \pm 0.1^{*}$ & $0.61 \pm 0.00$ & $6.7 \pm 0.2$ & $0.45 \pm 0.00$ \\
\hline
\end{tabular}

Concentrations $\left(\mathrm{g} \mathrm{I}^{-1}\right.$ ) of L-lactic acid, xylitol, and D-xylulose produced and yield of L-lactic acid on D-xylose consumed ( $\mathrm{g} \mathrm{g}{ }^{-1}$ ) by C. sonorensis IdhL strains in which the native D-xylose pathway was intact (C29, C281 and C282-C284). All strains except C29 expressed XYLA alone (C281) or with ScXKS1 (C282-C284). Cells were cultivated in $\mathrm{CaCO}_{3}$ buffered, YP medium with $50 \mathrm{~g} \mathrm{I}^{-1} \mathrm{D}$-xylose and $10 \mathrm{mM} \mathrm{MgCl}$ at $30^{\circ} \mathrm{C}, 100$ rpm. Results are the mean \pm sem from 3 to 6 replicate flasks. An asterisk indicates that the value is significantly different $(p<0.05)$ from values in the same column without an asterisk.

L-lactic acid production in anaerobic conditions by $C$. sonorensis expressing XYLA and SCXKS1 but lacking the native $\mathrm{D}$-xylose pathway

To determine the $X Y L A$-dependent ability of $C$. sonorensis transformants to produce L-lactic acid anaerobically several strains were cultivated in flasks sealed with water locks in $\mathrm{CaCO}_{3}$ buffered YP medium with $50 \mathrm{~g} \mathrm{l}^{-1} \mathrm{D}$ xylose. All XYLA containing strains consumed significantly $(\mathrm{p}<0.05)$ more $\mathrm{D}$-xylose than $\mathrm{C} 29$, although $\mathrm{D}$-xylose consumption by most strains was low (Figure 3 ).

D-xylose consumption generally reflected the ability of the strains to produce L-lactic acid. Strain C311 (xyl1 $\Delta::$ $X Y L A)$ appeared to produce slightly more L-lactic acid $\left(1.8 \pm 0.4 \mathrm{~g} \mathrm{l}^{-1}\right)$ than $\mathrm{C} 29\left(0.9 \pm 0.1 \mathrm{~g} \mathrm{l}^{-1}\right)$, although the amounts produced by either strain were very low and did not differ significantly ( $\mathrm{p}>0.05$, Figure 3 ). Additional expression of ScXKS1 (xyl1A::XYLA y::ScXKS1, C341 and $\mathrm{C} 342)$ resulted in a significant $(\mathrm{p}<0.05)$ increase in $\mathrm{L}$ lactic acid production $\left(2.5 \pm 0.3 \mathrm{~g} \mathrm{l}^{-1}\right)$ compared with C29 (Figure 3). Strains C345 and C346, from which both $X Y L 2$ and XYL1 had been deleted and in which both $X Y L A$ and ScXKS1 were expressed, produced significantly $(\mathrm{p}<0.05)$ more L-lactic acid $\left(5.0 \pm 0.3 \mathrm{~g}\right.$ lactic acid $\left.\mathrm{l}^{-1}\right)$ than the other strains containing only XYLA (Figure 3).

L-lactic acid production was highest $(\mathrm{p}<0.05)$ in C349 $\left(8.5 \pm 0.2 \mathrm{~g} \mathrm{l}^{-1}\right)$, in which two copies of XYLA were expressed in a $x y l 1 \Delta, x y l 2 \Delta, S c X K S 1$ background. However, the expression of two copies of XYLA in a $x y l 1 \Delta$ background (C313) or in a ScXKS1 xyl1 background (C348) in the presence of XYL2 did not enhance L-lactic acid production. C313 and C348 produced similar ( $\mathrm{p}>$ 0.05) amounts of L-lactic acid to strains C311, C341 and C342 (Figure 3).
Xylitol was produced only by C29 $\left(0.9 \pm 0.1 \mathrm{~g} \mathrm{l}^{-1}\right)$, which had the endogenous D-xylose utilisation pathway, and by strains C311 $\left(0.9 \pm 0.3 \mathrm{~g} \mathrm{l}^{-1}\right)$ and C313 $\left(1.0 \pm 0.4 \mathrm{~g} \mathrm{l}^{-1}\right)$, containing one or two copies of the xylose isomerase encoding gene, an intact $X Y L 2$ but no XYL1.

\section{Discussion}

The expression of the $l d h L$ gene in C. sonorensis resulted in transformants that produced L-lactic acid from Dxylose. The maximum L-lactic acid concentration in $\mathrm{CaCO}_{3}$-buffered minimal medium cultivations was $27 \mathrm{~g} \mathrm{l}^{-1}$ for strains with one copy of $l d h L$ (C29, PDC + and C184, $P D C$-), regardless of whether $P D C$ genes were present, and $31 \mathrm{~g} \mathrm{l}^{-1}$ for the strain containing two copies of $l d h L$ (C169, $P D C$-). Thus increasing the copy number of $l d h L$ from one to two had only a small effect on L-lactic acid production while deletion of the PDC genes did not significantly ( $\mathrm{p}>$ 0.05) affect L-lactic acid production (Table 1). C29, with one copy of the $l d h L$ gene, did not produce acetate or ethanol during the cultivation even though the wild type did, showing that LDH was able to compete effectively with $\mathrm{PDC}$ for pyruvate in a microaerobic $\mathrm{CaCO}_{3}$-buffered Dxylose cultivation. The same phenomenon was observed on $\mathrm{D}$-glucose medium with the L-lactate producing $C$. sonorensis strains with intact $P D C$ genes [6].

In non-buffered conditions, strains with one (C184) and two (C169) copies of $l d h L$ produced similar amounts of Llactic acid, since production of only $13 \mathrm{~g} \mathrm{l}^{-1}$ L-lactic acid had lowered the $\mathrm{pH}$ to 2.8 , causing further uptake of Dxylose to stop. This was comparable with the $15 \mathrm{~g} \mathrm{l}^{-1} \mathrm{~L}$ lactic acid produced by $S$. stipitis [11] in non-buffered conditions in $\sim 80 \mathrm{~h}$. Both the production rate $\left(0.31 \mathrm{~g} \mathrm{l}^{-1}\right.$ $\left.\mathrm{h}^{-1}\right)$ and yield of L-lactic acid on D-xylose $\left(\sim 0.54 \mathrm{~g} \mathrm{~g}^{-1}\right)$

Table 4 Xylose reductase and xylitol dehydrogenase activities in $x y / 1 \Delta$ and $x y / 2 \Delta$ strains

\begin{tabular}{llll}
\hline Strains & Genotype & $\begin{array}{l}\text { Xylose reductase activity } \\
\mathbf{m U}[\mathbf{m g ~ p r o t e i n}]^{-\mathbf{1}}\end{array}$ & $\begin{array}{l}\text { Xylitol dehydrogenase activity } \\
\mathbf{m U}_{[\mathbf{m g ~ p r o t e i n}]^{-1}}\end{array}$ \\
\hline wild type & & $75 \pm 1.6$ & $571 \pm 21$ \\
C689, C690 & xyl14 & $2 \pm 0.3$ & $625 \pm 47$ \\
C684, C685, C686 & xyl2 & $74 \pm 0.9$ & $126 \pm 4$ \\
\hline
\end{tabular}

NADPH-dependent xylose reductase and xylitol dehydrogenase activities in C. sonorensis strains in which the $X Y L 1$ or $X Y L 2$ gene were disrupted. Wild type $C$. sonorensis, xyl1 $\Delta$ strains (C689 and C690) and xyl2 $\Delta$ strains (C684, C685 and C686) were grown in YNB with $50 \mathrm{~g} \mathrm{I^{-1 }}$ D-xylose for $24 \mathrm{~h}$. Results are mean \pm sem for duplicate activity measurements of wild type strain, two $x y / 1 \Delta$ strains or three $x y / 2 \Delta$ strains. 


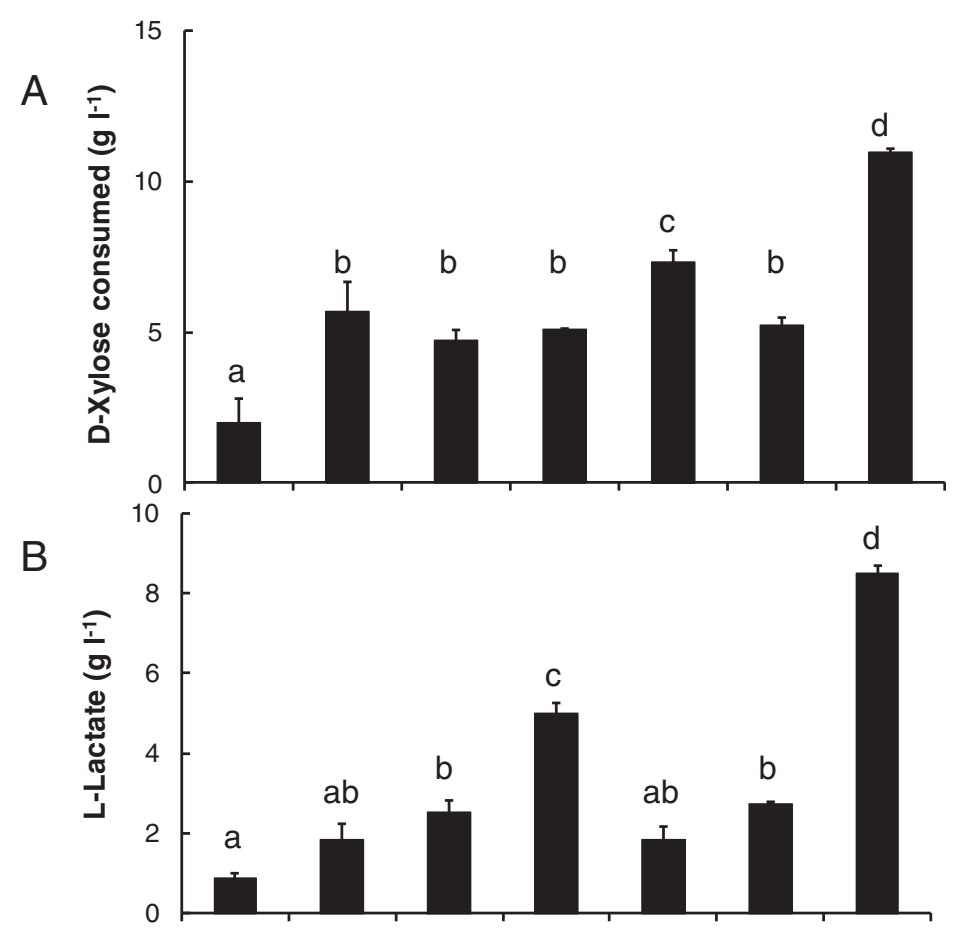

\begin{tabular}{|l|c|c|c|c|c|c|c|}
\hline XYL1 & + & $\Delta$ & $\Delta$ & $\Delta$ & $\Delta$ & $\Delta$ & $\Delta$ \\
\hline XYL2 & + & + & + & $\Delta$ & + & + & $\Delta$ \\
\hline ScXKS1 & - & - & + & + & - & + & + \\
\hline XYLA & 0 & 1 & 1 & 1 & 2 & 2 & 2 \\
\hline Strain & C29 & C311 & $\begin{array}{l}\text { C341 } \\
\text { C342 }\end{array}$ & $\begin{array}{c}\text { C345 } \\
\text { C346 }\end{array}$ & C313 & C348 & C349 \\
\hline
\end{tabular}

Figure 3 Xylose consumption and L-lactic acid production in anaerobic cultivation. Concentration ( $\left.\mathrm{g} \mathrm{I}^{-1}\right)$ of D-xylose consumed (A) and L-lactic acid produced (B) in anaerobic cultivations of $C$. sonorensis IdhL strains with the native D-xylose pathway disrupted and expressing XYLA alone (C311, XYLA, xyl1 C348, $\left.2^{*} X Y L A, S C X K S 1, x y / 1 \Delta ; C 349,2^{*} X Y L A, S C X K S 1, x y / 1 \Delta, x y / 2 \Delta\right)$, with C29 as the control. Strains were cultivated at $30^{\circ} \mathrm{C}$ in $50 \mathrm{ml}^{-}$of $\mathrm{CaCO}_{3}$-buffered, YP-50 $\mathrm{g} \mathrm{I}^{-1}$ D-xylose with $10 \mathrm{mM} \mathrm{MgCl} 2$ in $100 \mathrm{ml}$ flasks sealed with water locks for $146 \mathrm{~h}$. Initial OD600 was 12. Results are averages of duplicate flasks. Error bars indicate sem. Bars with the same letter (a to $d)$ in the same graph did not differ significantly $(p>0.05)$.

were higher than those previously published for production of L-lactic acid from D-xylose by yeast in nonbuffered conditions [11].

Adaptation of cells to D-xylose strongly affected L-lactic acid production in cultivations with mixed sugars (D-glucose and D-xylose). The D-xylose consumption rate and L-lactic acid concentration were significantly $(\mathrm{p}<0.05)$ higher and xylitol concentration was lower in cultures inoculated with D-xylose-grown cells, compared to cultures inoculated with D-glucose-grown cells (Figure 1). The enhanced L-lactic acid production with D-xylose-grown inoculum is probably due to higher xylose reductase, xylitol dehydrogenase and xylulokinase activities, which in turn reflected higher levels of transcription of the corresponding genes. Yeast cultures inoculated with D-xylose-grown cells had 2-, 16- and 3-fold higher xylose reductase, xylitol dehydrogenase and xylulokinase in vitro activities, respectively, compared to the cultures inoculated with Dglucose-grown cells (Figure 1), while the mRNA levels of XYL1, XYL2 and XKS1 genes were 3-, 5-, and 3-fold higher, respectively (Figure 2). The yeast C. tenuis [23], S. stipitis and P. tannophilus [24] also show enhanced xylose reductase and xylitol dehydrogenase activities in Dxylose-grown cells compared to D-glucose-grown cells, whereas there was no clear effect of the carbon source in C. utilis [12]. The effect and extent of this effect of carbon source on the activity of enzymes involved in D-xylose metabolism is apparently species dependent.

Fungal L-lactic acid production from D-xylose has been described in S. stipitis and C. utilis strains expressing the 
$L D H$ gene of $L$. helveticus and $B$. taurus, respectively $[11,12]$, and additionally in the filamentous fungus $R$. oryzae [8-10]. In the present study, the $C$. sonorensis transformant with one copy of $l d h L$ (C29) produced amounts of L-lactic acid comparable to that produced by S. stipitis with one copy of ldhL [11] in $\mathrm{CaCO}_{3}$ buffered YNB medium with $\mathrm{D}$-xylose, but at a lower rate (Table 5). The $C$. sonorensis $l d h L$ strain utilised D-xylose more efficiently and produced more L-lactic acid with a higher yield and rate than $R$. oryzae CBS 112.07 in minimal Dxylose medium [10] or $C$. utilis $L D H$ with only its endogenous D-xylose metabolic pathway [12] (Table 5). Over-expression of exogenous XR, XDH and XK encoding genes in $C$. utilis has, however, resulted in much higher L-lactic acid production than with the native pathway, particularly when a xylose reductase with dual cofactor specificity was introduced [12] (up to $67.2 \mathrm{~g} \mathrm{l}^{-1}$, Table 5). Thus, both enzyme activity and co-factor availability may be limiting, even in D-xylose utilising strains.

In bacteria, D-xylose is converted to D-xylulose directly by xylose isomerase with no redox cofactors involved. A xylose isomerase gene has also been cloned from the obligatory anaerobic fungus Piromyces sp. E2 [25]. Its expression in C. sonorensis resulted in an active enzyme with in vitro activity of $100 \mathrm{mU} \mathrm{mg}^{-1}$ (Table 2), which was lower than what has been reported in $S$.

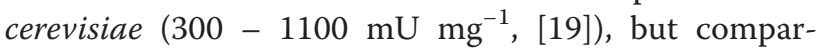
able to the activity of the $E$. coli xylose isomerase in
Hansenula polymorpha (50 - $190 \mathrm{mU} \mathrm{mg}^{-1}$, [26]). Even though the in vitro xylose isomerase activity was low, it was functional in vivo, as indicated by production of L-lactic acid from D-xylose in strains which had the xylose isomerase encoding gene expressed and xylose reductase and xylitol dehydrogenase encoding genes deleted.

Under anaerobic conditions L-lactic acid production was significantly $(\mathrm{p}<0.05)$ improved in strains expressing XYLA and in which the endogenous D-xylose pathway was disrupted, compared to the strain having the native D-xylose pathway (Figure 3). L-lactic acid production was further improved by expressing ScXKS1 in the $X Y L A$ strains with the disrupted native pathway (Figure 3). Like ethanol production in $H$. polymorpha with xylose isomerase [26], the best L-lactic acid production was detected in strains from which both xylose reductase and xylitol dehydrogenase encoding genes had been deleted and which also expressed ScXKS1 (Figure 3). A similar result has been observed for anaerobic ethanol production with $C$. sonorensis strains with no $l d h L$ added, but having XYLA alone or together with ScXKS1 expressed and the xylose reductase gene with or without the xylitol dehydrogenase gene deleted (K. Koivuranta, unpublished data). Xylose isomerase activity was probably limiting, since strains with two copies of the gene produced more L-lactic acid than strains with only one copy, when both XYL1 and XYL2 were lacking and ScXKS1 was expressed.

Table $\mathbf{5} \mathbf{L}$ - lactic acid production from xylose with various yeast strains

\begin{tabular}{|c|c|c|c|c|c|c|c|c|}
\hline Strain & Xylose $\left(\mathrm{g} \mathrm{I}^{-1}\right)$ & Cultivation time (h) & Lactic acid $\left(\mathrm{g} \mathrm{I}^{-1}\right)$ & $\begin{array}{l}\text { Lactic acid } \\
\text { production } \\
\text { rate }\left(\mathrm{g} \mathrm{h}^{-1} \mathrm{I}^{-1}\right)\end{array}$ & $\begin{array}{l}\text { Lactic acid } \\
\text { yield }\left(\mathbf{g ~ g}^{-1}\right)\end{array}$ & Xylitol $\left(\mathrm{g} \mathrm{I}^{-1}\right)$ & Genetic modifications & Reference \\
\hline $\begin{array}{l}\text { Candida } \\
\text { sonorensis }\end{array}$ & 50 & 168 & 26.7 & 0.16 & 0.53 & $0^{*}$ & $\begin{array}{l}\text { Lactobacillus } \\
\text { helveticus IdhL }\end{array}$ & This study \\
\hline $\begin{array}{l}\text { Rhizopus oryzae } \\
\text { CBS } 147.22\end{array}$ & 59 & 190 & 15.2 & 0.08 & 0.38 & 2.0 & Wild type & 10 \\
\hline $\begin{array}{l}\text { Scheffersomyces } \\
\text { stipitis }\end{array}$ & 50 & 72 & 31.0 & 0.43 & 0.60 & $\leq 1.3$ & L. helveticus IdhL & 11 \\
\hline S. stipitis & 100 & 147 & 58.0 & 0.39 & 0.58 & $\leq 1.3$ & L. helveticus IdhL & 11 \\
\hline Candida utilis & 100 & 75 & 2.9 & 0.04 & 0.03 & 1.2 & $\begin{array}{l}\text { PDC-, } 2 \times \text { Bos } \\
\text { taurus IdhL }\end{array}$ & 12 \\
\hline C. utilis & 100 & 75 & 43.8 & 0.58 & 0.44 & 25.4 & $\begin{array}{l}\text { PDC-, } 2 \times \text { B. taurus IdhL, } \\
\text { Candida shehatae XR } \\
\text { (NADPH preferring), } \\
\text { C. shehatae XDH } \\
\text { (NAD }{ }^{+} \text {dependent), } \\
\text { S. stipitis XK }\end{array}$ & 12 \\
\hline C. utilis & 100 & 75 & 67.2 & 0.93 & 0.67 & 3.2 & $\begin{array}{l}\text { PDC-, } 2 \times \text { B. taurus IdhL, } \\
\text { C. shehatae XR } \\
\text { (NADH preferring), } \\
\text { C. shehatae XDH } \\
\text { (NAD dependent), } \\
\text { S. stipitis XK }\end{array}$ & 12 \\
\hline
\end{tabular}

L-Lactic acid production titre, rate and yield with various yeast or fungal strains in buffered minimal xylose medium. Initial xylose and xylitol amounts at the end of cultivations are also indicated. Genetic modifications (IdhL $=$ L-lactate dehydrogenase, $X R=x y l o s e$ reductase, $X D H=x y l i t o l$ dehydrogenase, $X K=x y l u l o k i n a s e)$ have been indicated. *All xylitol had been consumed at the end of cultivation, but in maximum $4.6 \mathrm{~g} \mathrm{I}^{-1}$ xylitol had been produced. 


\section{Conclusions}

C. sonorensis expressing the $l d h L$ gene of $L$. helveticus converted D-xylose to L-lactic acid via the endogenous D-xylose pathway, especially when the strains were adapted on D-xylose to increase their xylose reductase, xylitol dehydrogenase and xylulokinase activities.

We demonstrated for the first time L-lactic acid production from $\mathrm{D}$-xylose under anaerobic conditions. To obtain anaerobic L-lactic acid production, it was necessary to replace the endogenous D-xylose pathway with a xylose isomerase encoding gene. Under anaerobic conditions, the best L-lactic acid production occurred with the strain deleted of endogenous xylose reductase and xylitol dehydrogenase encoding genes and expressing genes of Piromyces sp. xylose isomerase and S. cerevisiae xylulokinase.

Promising results in both micro- and anaerobic Dxylose cultivations with $C$. sonorensis strains for L-lactic acid production encourages further strain development using both evolutionary engineering (mutagenesis and selection) and metabolic engineering (e.g. expression of the non-oxidative pentose phosphate pathway) to improve lactate production.

\section{Methods}

\section{Strains and plasmids}

Microbial strains and plasmids used in the study are listed in Tables 6 and 7. Plasmids pCM29 and pVR103 were provided by Cargill (formerly NatureWorks LLC and Cargill Dow). Escherichia coli DH5 $\alpha$ (Gibco BRL,
Gaithersburg, MD, USA) was routinely used as a host for cloning and manipulation. C. sonorensis ATCC32109 (American Type Culture Collection) was used throughout the study as a control and was the parental strain for all transformants generated in this work.

\section{Media and culture conditions}

Microaerobic (100 rpm) flask cultivations were carried out using two sequential pre-cultures to inoculate the production phase, as follows. Pre-culture 1: YP (yeast extract $10 \mathrm{~g} \mathrm{l}^{-1} \mathrm{w} / \mathrm{v}$, peptone $20 \mathrm{~g} \mathrm{l}^{-1} \mathrm{w} / \mathrm{v}$ ) with $50 \mathrm{~g} \mathrm{l}^{-1} \mathrm{D}$ glucose (YPD) or $50 \mathrm{~g} \mathrm{l}^{-1} \mathrm{D}$-xylose (YPX) was inoculated with a single colony from agar-solidified YPX or YPD and grown $\mathrm{o} / \mathrm{n}$ with shaking at $250 \mathrm{rpm}$ at $30^{\circ} \mathrm{C}$. Preculture 2: $2 \times 50 \mathrm{ml}$ of YNB (yeast nitrogen base without amino acids, $6.7 \mathrm{~g} \mathrm{l}^{-1}$ (Difco, Sparks, MD, USA)) with 0.5 M 2-[N-Morpholino]ethanesulfonic acid (MES) $\mathrm{pH} 5.5$ and $50 \mathrm{~g} \mathrm{l}^{-1}$ D-glucose (YGM) or $50 \mathrm{~g} \mathrm{l}^{-1} \mathrm{D}$ xylose (YXM) in $250 \mathrm{ml}$ flasks were inoculated from pre-culture 1 to $\mathrm{OD}_{600}$ of $0.1-0.2$ and grown $\mathrm{o} / \mathrm{n}$ with shaking at $250 \mathrm{rpm}$ at $30^{\circ} \mathrm{C}$. The $\mathrm{OD}_{600}$ of pre-culture 2 was typically around 11 at the time when cells were collected and residual sugar remained in the medium. Lactate production phase: cells from the second pre-culture flasks were collected by centrifugation and transferred to $50 \mathrm{ml}$ of YNB medium with $50 \mathrm{~g} \mathrm{l}^{-1} \mathrm{D}$-xylose to give an initial $\mathrm{OD}_{600}$ of $10-15$, then incubated at $100 \mathrm{rpm}$ in $250 \mathrm{ml}$ flasks containing $2 \mathrm{~g} \mathrm{CaCO}_{3}$ (final concentration $\left.40 \mathrm{~g} \mathrm{l}^{-1} \mathrm{CaCO}_{3}\right)(\mathrm{YXC})$. Alternatively, C. sonorensis $\mathrm{C} 169$ strain $\left(P D C-, 2^{*} l d h L\right)$, was collected by centrifugation and

Table 6 Plasmids used in the study

\begin{tabular}{|c|c|c|}
\hline Plasmid & Description & Reference or source \\
\hline pCM29 & $S C P_{P D C 1}-h p h-S C T_{G A L 10^{-} X Y L A}$ & C. Miller, NatureWorks LLC \\
\hline pVR103 & $S C P_{T E F}-S C X K S 1-S C T_{G A L 10}$ & V. Rajgarhia, NatureWorks LLC \\
\hline pMI271 & $\mathrm{CSP}_{T D H 1}-h p h-S C T_{G A L 10}$ & [6] \\
\hline pMI278 & $C_{S} P_{G P D 1}-G 418^{R}-S C T_{M E L 5}-C S P P G K 1-B m L D H-S C T_{G A L 10}$ & [6] \\
\hline pMI281 & $\operatorname{CSP}_{T D H 1}-B m L D H-S C T_{G A L 10}$ & This study \\
\hline pMI400 & $S C P_{P D C 1}-h p h-S C T_{G A L 10}-X Y L A$ & This study \\
\hline pMI403 & $\mathrm{CSP}_{T D H 1}-G 418^{R}-S C T_{M E L 5}-C_{S} P_{P G K 1}-X Y L A-S C T_{G A L 10}$ & This study \\
\hline pMI406 & $S C X K S 1-S C T_{G A L 10}$ & This study \\
\hline pMI409 & CSXYL2 5'-CSP $P_{T D H 1}-B m L D H-S C T_{G A L 10}$ & This study \\
\hline pMI410 & CSXYL2 5'-CSP $P_{T D H 1}-B m L D H-S C T_{G A L 10^{-}}-\operatorname{Cs} X Y L 23^{\prime}$ & This study \\
\hline pMI411 & $\operatorname{CSXYL1} 5^{\prime}-\operatorname{CSP}_{T D H 1}-B m L D H-S C T_{G A L 10}$ & This study \\
\hline pMI412 & 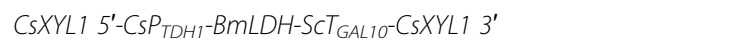 & This study \\
\hline pMl417 & CSXYL1 5'-CSP $P_{T D H 1}-G 418^{R}-S C T_{M E L 5}-C_{S P} P_{P G K 1}-X Y L A-S C T_{G A L 10^{-}}-\operatorname{CS} X Y L 13^{\prime}$ & This study \\
\hline pMI423 & $\operatorname{CSP}_{P G K 1}-X Y L A-S C T_{G A L 10}-C S P_{T D H 1}-h p h-S C T_{G A L 10}$ & This study \\
\hline pMI424 & CSXYL1 5'-CSP $P_{T D H 1}-G 418^{R}-S C T_{M E L 5}-C_{S} P_{P G K 1}-S C X K S 1-S C T_{G A L 10}-\operatorname{CSXYL1} 3^{\prime}$ & This study \\
\hline pMI425 & CSXYL2 5'-CSP $P_{T D H 1}-h p h-S C T_{M E L 5}-C_{S} P_{P G K 1}-S C X K S 1-S C T_{G A L 10}-C S X Y L 23^{\prime}$ & This study \\
\hline pKK02 & $\operatorname{CSXYL2} 5^{\prime}-\operatorname{CSP}_{T D H 1}-h p h-S C T_{M E L 5}-\operatorname{Cs} X Y L 23^{\prime}$ & This study \\
\hline pKK03 & CSXYL1 5'-CSP $P_{T D H 1}-G 418^{R}-S C T_{M E L 5}-C S X Y L 13^{\prime}$ & This study \\
\hline
\end{tabular}


Table 7 Candida sonorensis ATCC32109 derived strains constructed and studied in this work

\begin{tabular}{|c|c|c|}
\hline Strains & Description & Reference or plasmid(s) used \\
\hline C29 & $x:: / d h L$ & {$[6]$} \\
\hline C169 & $p d c 1 \Delta: I d h L p d c 2 \Delta: I d h L$ & [6] \\
\hline C184 & $p d c 1 \Delta: I d h L p d c 2 \Delta$ & [6] \\
\hline C281 & $x:: I d h L y:: X Y L A$ & $\mathrm{pMl} 403$ \\
\hline C282, C283, C284 & $x:: I d h L y:: X Y L A$ z::SCXKS1 & pMl403, pMl425 \\
\hline C311 & $x:: I d h L x y / 1 \triangle: X Y L A$ & $\mathrm{pM} 4417$ \\
\hline C313 & $x:: / d h L$ xyl1 $\triangle: X Y L A$ y::XYLA & $\mathrm{pM} 4417$ \\
\hline C345, C346 & 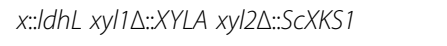 & pMI417, pMI425 \\
\hline C349 & 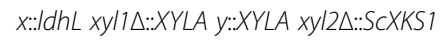 & pMI417, pMI425 \\
\hline C341, C342 & $x:: / d h L$ xy/1 $1:: X Y L A$ y::SCXKS1 & pMI417, pMI425 \\
\hline C348 & $x:: 1 d h L$ xyl1 $1:: X Y L A$ y::XYLA z::SCXKS1 & pMI417, pMI425 \\
\hline C684, C685, C686 & $x y \mid 2 \Delta$ & pKK02 \\
\hline C689, C690 & $x y / 1 \Delta$ & pKK03 \\
\hline
\end{tabular}

$x::$ and $y::$ indicate that the site of integration is not known.

transferred into $50 \mathrm{ml}$ of YNB medium with $30 \mathrm{~g} \mathrm{l}^{-1} \mathrm{D}$ glucose and $30 \mathrm{~g} \mathrm{l}^{-1} \mathrm{D}$-xylose and $40 \mathrm{~g} \mathrm{l}^{-1} \mathrm{CaCO}_{3}$ (YGXC).

Microaerobic cultures were incubated with shaking at $100 \mathrm{rpm}$ at $30^{\circ} \mathrm{C} .2 \mathrm{ml}$ samples were removed daily. Culture supernatant samples were analysed by HPLC for sugars and metabolites. For measurement of xylose reductase activity, the biomass was generated in YGM or YXM.

For anaerobic flask cultivations of the $C$. sonorensis strain expressing Piromyces sp XYLA, pre-cultures were obtained by inoculating $50 \mathrm{ml}$ of YPD medium with $10 \mathrm{mM} \mathrm{MgCl}_{2}$ in $250 \mathrm{ml}$ flasks with cells grown on agar-solidified YPD, and incubating o/n at $250 \mathrm{rpm}, 30^{\circ}$ C. $\mathrm{OD}_{600}$ was measured and the amount of cells equivalent to $\mathrm{OD}_{600} 12$ in $50 \mathrm{ml}$ was collected by centrifugation and resuspended in $50 \mathrm{ml}$ of YPX medium with $10 \mathrm{mM} \mathrm{MgCl} 2$ and transferred into a $100 \mathrm{ml}$ flask containing $1.2 \mathrm{~g} \mathrm{CaCO}_{3}$ (final concentration $24 \mathrm{~g} \mathrm{l}^{-1} \mathrm{CaCO}_{3}$ ). Flasks were sealed with water locks. The cultures were incubated at $30^{\circ} \mathrm{C}$ with $100 \mathrm{rpm}$ shaking. Samples were collected after 146 hours cultivation.

For xylose isomerase activity measurements, cultures of $50 \mathrm{ml}$ YPD medium with $10 \mathrm{mM} \mathrm{MgCl}_{2}$ in $250 \mathrm{ml}$ flasks were inoculated with cells grown on agar-solidified YPD and incubated $\mathrm{o} / \mathrm{n}$ at $250 \mathrm{rpm}, 30^{\circ} \mathrm{C}$. A $5 \mathrm{ml}$ aliquot was removed for determination of xylose isomerase activity.

Agar-solidified medium (YPD or YPX) contained $20 \mathrm{~g} \mathrm{l}^{-1}$ carbohydrate, rather than $50 \mathrm{~g} \mathrm{l}^{-1}$.

\section{Northern analysis}

RNA was isolated from C169 cells cultivated overnight in YGM or YXM medium using Trizol reagent (Invitrogen, Carlsbad, CA, USA), denatured with glyoxal prior to electrophoresis as described in Sambrook and Russell [27], blotted onto nylon membranes (Hybond-N, Amersham Biosciences, Little Chalfont, UK), and hybridized with $\left[\alpha-{ }^{32} \mathrm{P}\right] \mathrm{dCTP}$ (Amersham Biosciences) labelled probes as described previously [28]. The XYL1, XYL2 and XKS1 genes were used as probes, in addition to $S$. cerevisiae $A C T 1$ and $C$. sonorensis PGK1 genes, which were used to standardise the mRNA levels in quantification.

\section{Enzymes, primers, and chemicals}

Restriction enzymes, DNA-modifying enzymes, and other molecular reagents were obtained from New England Biolabs (Ipswich, MA, USA), Thermo Scientific (Rockford, IL, USA), Promega (Wisconsin, MA, USA), Agilent Technologies (Santa Clara, CA, USA), and Roche (Germany). All common chemicals were purchased from Sigma (USA). Primers for PCR and sequencing were synthesized by Sigma Genosys (Little Chalfont, UK).

\section{Cloning of $X Y L 1, X Y L 2$ and $X K S 1$ genes}

Xylose reductase $(X Y L 1)$, xylitol dehydrogenase (XYL2) and xylulokinase $(X K S 1)$ homologues were cloned from a $C$. sonorensis genomic lambda library [6] by hybridization. $X Y L 1$ and XKS1 genes were isolated as PCR products generated using degenerate oligonucleotide primers XR1, XR5, $\mathrm{XK} 3$ and XK6, corresponding to consensus sequences of known $X Y L 1$ and XKS1 genes (Table 8). The XYL2 gene was isolated by using the $P$. stipitis $X Y L 2$ gene [29] as a probe.

Cloning of the xylulokinase (XKS1) gene resulted in a fragment with $1.8 \mathrm{~kb}$ coding region, and $1.5 \mathrm{~kb}$ upstream and $0.5 \mathrm{~kb}$ downstream regions from the open reading frame. In Southern analysis only one xylulokinase encoding gene was detected. The highest overall amino acid 
Table 8 Oligonucleotides used in the study

\begin{tabular}{lll}
\hline Oligo name & Sequence & Use \\
\hline 133PirXI & ggacatgcatgcatttggggtacccaaggcttccgctctagaaaacaatggctaaggaatatttcccacaaattc & Piromyces Sp. XYLA \\
134PirXI & ccaatgcattggttcctgcagggaattcgacaacatcaaagtctgggttagtg & Piromyces Sp. XYLA \\
Sc135XKS1ATG & aaggccttgcggccgcctctagaaaacaatgttgtgttcagtaattcagagac & Saccharomyces cerevisiae XKS1 \\
Sc135XKS1Bgl2 & gaaaaggccttgttcaatggaaatttagcctcgcg & Saccharomyces cerevisiae XKS1 \\
Cs141XR & actgtcgagctcgtttaaaccttcaccttaaattccccaattgag & Candida sonorensis XYL1 5' region \\
Cs142XR & actgacgcgtcgactcttgtttgattgtgtgttgattgatc & Candida sonorensis XYL1 5' region \\
Cs143XR & ggcccgcggccgctaagcagctagtataggcaagatgtag & Candida sonorensis XYL1 3' region \\
Cs144XR & gggacgggcccaactgtaataatccgactttcaacg & Candida sonorensis XYL1 3' region \\
Cs137XDH & actgtcgagctcgtttaaacacctattcgggagtcaatcaaccat & Candida sonorensis XYL2 5' region \\
Cs138XDH & actgacgcgtcgacgtatgtataataaggtatgattctgg & Candida sonorensis XYL2 5' region \\
CS139XDH & ggcccgcggccgctaggctagttttctaaaattttggtg & Candida sonorensis XYL2 3' region \\
CS140XDH & gggacgggcccaagtatgagaaatattgatgatatag & Candida sonorensis XYL2 3' region \\
XR1 & gghtaymgwttdttygayggtgc & XYL1 degenerative oligo \\
XR5 & ccadkyccawggrtyrttraatct & XYL1 degenerative oligo \\
XK3 & tcrtanarrttcatnccrca & XKS1 degenerative oligo \\
XK6 & tcracycarcarytsaa & XKS1 degenerative oligo \\
\hline
\end{tabular}

sequence identity, in comparison with known fungal xylulokinase encoding genes, was $68 \%$.

\section{Construction of $X Y L 1$ expression and targeting vectors}

Plasmid pMI317 was constructed for the expression of S. stipitis XYL1 [30] under the control of the C. sonorensis PGK1 promoter [6]. The S. stipitis XYL1 gene, encoding a $\mathrm{NAD}(\mathrm{P}) \mathrm{H}$ dependent xylose reductase, was obtained from plasmid pUA103 [31]. The plasmid also contained the hygromycin resistance gene $(E$. coli $h p h)$ for the selection of transformants.

For replacement of the $C$. sonorensis XYL1 locus, a vector with $X Y L 1$ targeting sequences was constructed. The C. sonorensis XYL1 5' region was PCR amplified with primers Cs141XR and Cs142XR (Table 8) from a genomic lambda library clone, CsXRlambda 4. The PCR product was cut with $S a c \mathrm{I}+\mathrm{SalI}$, the $0.6 \mathrm{~kb}$ fragment was isolated from a gel and ligated to a $5 \mathrm{~kb} \mathrm{SacI}+\mathrm{SalI}$ fragment of pMI281. The resulting plasmid was named pMI411. Vector pMI281 was prepared by cutting pMI278 [6] with $X b a \mathrm{I}$, isolating and circularizing the $5 \mathrm{~kb}$ fragment. The C. sonorensis XYL1 3' region was PCR amplified using primers Cs143XR and Cs144XR (Table 8) from the library clone CsXRlambda 4. The PCR product was cut with $N o t \mathrm{I}+A p a \mathrm{I}$, the $0.6 \mathrm{~kb}$ fragment was gel purified and ligated to the $5.4 \mathrm{~kb} N o t \mathrm{I}+$ ApaI fragment of pMI411. The resulting plasmid was named pMI412.

\section{Construction of a XYL2 targeting vector}

For replacement of the C. sonorensis XYL2 locus, a vector with $X Y L 2$ targeting sequences was constructed. The C. sonorensis $X Y L 25^{\prime}$ region was PCR amplified using primers Cs137XDH and Cs138XDH (Table 8) with the lambda library clone $\mathrm{XDH}$ lambda $1 / 1 / 1$ as a template. The PCR product was cut with $\mathrm{SacI}+\mathrm{SalI}$, the $0.6 \mathrm{~kb}$ fragment was isolated from gel and ligated to the $5 \mathrm{~kb}$ SacI + SalI fragment of pMI281 to generate plasmid pMI409. The C. sonorensis XYL2 3' region was PCR amplified using primers Cs139XDH and Cs140XDH (Table 8) and lambda library clone CsXDH lambda 1/1/1 as a template. The PCR product was cut with NotI-ApaI, the $0.5 \mathrm{~kb}$ fragment was isolated from a gel and ligated to the $5.6 \mathrm{~kb}$ NotI-ApaI fragment of pMI409 to generate plasmid pMI410.

\section{Construction of a XYLA expression vector}

The vector containing the Piromyces XYLA gene [25] under the $C$. sonorensis PGK1 promoter and $S$. cerevisiae GAL10 terminator was constructed as follows. The Piromyces XYLA gene was modified by adding a KpnI restriction site to the $5^{\prime}$ end of gene. First, the Piromyces $X Y L A$ region from the ATG start codon to a single AgeI site was PCR amplified using primers 133PirXI and 134PirXI (Table 8) with pCM29 as template. The PCR product was cut with AgeI-KpnI and the $0.5 \mathrm{~kb}$ fragment was isolated from a gel. pCM29 was cut with AgeI and the $8.2 \mathrm{~kb}$ fragment was gel purified, partially digested with KpnI, and the $6.5 \mathrm{~kb}$ AgeI-KpnI fragment was gel purified and ligated to the $0.5 \mathrm{~kb}$ PCR product, generating plasmid pMI400. In the following step the XYLA gene was placed under control of the $C$. sonorensis PGK1 promoter in a vector containing the $G 418^{\mathrm{R}}$ marker gene. pMI278 was cut with $\mathrm{BamHI}$, filled in with Klenow enzyme and partially digested with XbaI. The $6.7 \mathrm{~kb}$ 
fragment was isolated from a gel. pMI400 was cut with Sbfl, made blunt ended with T4 polymerase, and cut with $\mathrm{XbaI}$. The $1.3 \mathrm{~kb}$ fragment was isolated from a gel and ligated to the $6.7 \mathrm{~kb}$ fragment of pMI278. The resulting plasmid was named pMI403. In addition, C. sonorensis XYL1 targeting sequences from pMI412 (see above), were incorporated into pMI403. pMI412 was cut with SalI-NotI and the $4.0 \mathrm{~kb}$ fragment was isolated from a gel and ligated to the $5.0 \mathrm{~kb}$ SalI-NotI fragment of pMI403. The resulting plasmid was named pMI417. Yeast transformations were carried out with SacI-ApaI or PmeI-PspOMI cut pMI417.

\section{Construction of XKS1 expression vectors}

The vector containing the S. cerevisiae XKS1 gene [32] under the $C$. sonorensis PGK1 promoter and S. cerevisiae GAL10 terminator was constructed as follows. First, the G418 resistance gene in pMI403 was replaced with the hygromycin resistance gene. pMI403 was cut with EcoNI, filled in with Klenow enzyme, cut with SalI and the $6.5 \mathrm{~kb}$ fragment was isolated from a gel. The hygromycin resistance gene was obtained from pMI271 [6] digested with BamHI, filled in with Klenow enzyme, and digested with SalI. The 1.7 kb BamHI(blunt)-SalI fragment was isolated from a gel and ligated to the $6.5 \mathrm{~kb}$ EcoNI(blunt)-SalI fragment of pMI403. The resulting plasmid was named pMI423.

The 5' end of S. cerevisiae XKS1 gene was modified by PCR using primers Sc135XKS1ATG and Sc135XKS1Bgl2 (Table 8) with pVR103 as the template. The PCR product was cut with NotI-BglII, and the $0.3 \mathrm{~kb}$ fragment was ligated to the $4.6 \mathrm{~kb}$ NotI-BglII fragment of pVR103. The plasmid was named pMI406. Plasmid pMI425, containing the $S$. cerevisiae XKS1 and the hygromycin resistance gene between $C$. sonorensis XYL2 targeting sequences, was constructed by ligating together three fragments: a $5.0 \mathrm{~kb}$ XbaI-BamHI fragment from pMI410, a $1.8 \mathrm{~kb} X b a \mathrm{I}-$ BamHI fragment from pMI406, and a $2.8 \mathrm{~kb} X b a \mathrm{I}$ fragment from pMI423. Targeted integration (XYL2 locus) in yeast transformations was carried out with PmeI-ApaI, SacI-ApaI or PmeI-PspOMI cut pMI425 and random integration was carried out with SalI-NotI cut pMI425.

\section{Construction of XYL1 and XYL2 deletion cassettes}

For the replacement of $C$. sonorensis $X Y L 2$ with the hygromycin resistance gene, plasmid pMI 425 was digested with AflII and NotI, the ends were filled in with Klenow enzyme, and the $5.7 \mathrm{~kb}$ fragment was circularized to form pKK02. PmeI-PspOMI cut pKK02 was used in yeast transformation.

For the deletion of the C. sonorensis $X Y L 1$ gene, vector pMI424, with XYL1 targeting sequences and the G418 ${ }^{\mathrm{R}}$ marker gene, was constructed by ligating three fragments, a $5.1 \mathrm{~kb}$ Xbal-BamHI from pMI412, a $1.8 \mathrm{~kb}$
XbaI-BamHI fragment from pMI406, and a $2.7 \mathrm{~kb} \mathrm{XbaI}$ fragment from pMI278. The resulting plasmid was named pMI424. Plasmid pMI424 was cut with AflII and NotI and filled in with Klenow enzyme, and the $5.6 \mathrm{~kb}$ fragment was circularized to form pKK03. PmeI-PspOMI cut pKK03 was used in yeast transformation.

\section{Construction of $C$. sonorensis strains}

Strains with one copy of $l d h L(C 29)$ and with $P D C 1$ and $P D C 2$ both deleted with one or two copies of $l d h L$ (C184 and C169, respectively) were constructed previously [6]. C. sonorensis was transformed using the lithium acetate method [33]. Transformants constructed for the present work were selected on YPD-hygromycin plates $(200 \mu \mathrm{g} / \mathrm{ml})$ or YPD-G418 ${ }^{\mathrm{R}}$ plates $(200 \mu \mathrm{g} / \mathrm{ml})$, as appropriate. The $C$. sonorensis strains generated by transformation are listed in Table 7.

\section{Preparation of crude extracts and enzyme assays}

Cell free extracts for enzyme activity measurements were prepared using Y-PER Yeast Protein Extraction Reagent (Thermo Scientific, Rockford, IL, USA). Protein concentrations were determined with the Advanced Protein Assay Reagent (Cytoskeleton Inc, Denver, CO, USA; for results in Table 3) or with the Lowry method [34]. Bovine serum albumin (Sigma, USA) was used as protein standard. Activities are expressed in units per milligram of protein. One $U$ was defined as the amount of enzyme required to reduce $1 \mu \mathrm{mol}$ of substrate per min. The XR, $\mathrm{XDH}$ and XI assays were performed in a Cobas Mira automated analyser (Roche, Germany).

Xylose reductase and xylitol dehydrogenase activities were determined as described previously $[35,36]$. Xylose isomerase activity was determined by monitoring the oxidation of NADH at $340 \mathrm{~nm}$ at $+30^{\circ} \mathrm{C}$. The reaction mixture contained $100 \mathrm{mM}$ TES (2-[[1,3-dihydroxy-2(hydroxymethyl)propan-2-yl]amino]ethanesulfonic acid)$\mathrm{NaOH}, \mathrm{pH}$ 7.0, $250 \mathrm{mM}$ D-xylose, $10 \mathrm{mM} \mathrm{MgCl}_{2}$, $0.6 \mathrm{mM} \mathrm{NADH}$ and $2.5 \mathrm{U}$ sorbitol dehydrogenase. Background was determined by measuring the activity without D-xylose.

Xylulokinase activity was determined in a two-step assay. In the first step the reaction mixture contained $50 \mathrm{mM}$ HEPES ((4-(2-hydroxyethyl)-1-piperazineethanesulfonic acid)/KOH pH 7.5, $5 \mathrm{mM}$ ATP, $6 \mathrm{mM} \mathrm{MgCl}_{2}$, $20 \mathrm{mM}$ xylulose. The background reaction was determined by adding water instead of D-xylose. After adding the enzyme (sample) the reaction was incubated at $+30^{\circ} \mathrm{C}$ for 0 and 240 seconds. The reaction was stopped by incubation at $+95^{\circ} \mathrm{C}$ for $5 \mathrm{~min}$. In the second step , $40 \mathrm{mM}$ HEPES-KOH pH 7.5, $10 \mathrm{mM} \mathrm{MgCl}_{2}, 2.5 \mathrm{mM}$ phosphoenol pyruvate, $0.2 \mathrm{mM} \mathrm{NADH}$ were added to the reaction mixture and the absorbance at $340 \mathrm{~nm}$ was measured before adding a mixture of myokinase (10 Units per 
reaction), pyruvate kinase (3.5 Units per reaction) and lactate dehydrogenase (10 Units per reaction). The reaction mixture was incubated for 1 hour and absorbance at $340 \mathrm{~nm}$ was measured. The xylulokinase activity was calculated from the ADP produced during the reaction.

\section{Analytical methods}

Culture supernatants were analysed by HPLC for L-lactic acid, D-xylose, xylitol, xylulose, pyruvic acid, acetic acid, glycerol and ethanol, as described in Ilmén et al. [6].

\section{Nucleotide sequence accession numbers}

Sequence data from this article have been deposited with the EMBL database under the accession numbers HE792813, HE792814 and HE792815.

\section{Statistical analysis}

Data is given as mean \pm standard error of the mean (sem). Significant differences between two strains or conditions were determined by the Student t-test. Differences between three or more strains or conditions were assessed by analysis of variance (ANOVA) and Fisher's multiple range test, when appropriate.

\section{Competing interests}

PS is an employee of Cargill, which has financial interest in lactic acid producing microorganisms described here.

\section{Authors' contributions}

KTK carried out the molecular genetic studies, enzyme activity measurements and flask cultivations and drafted the manuscript. MI participated in the molecular genetic studies and flask cultivations and in the design of the study. MW performed the statistical analyses and helped to draft the manuscript. LR, PS and MP participated in study design and coordination and helped to draft the manuscript. PS also conceived of the study. All authors read and approved the final manuscript.

\section{Acknowledgements}

Merja Helanterä and Seija Rissanen are thanked for excellent technica assistance. Dr Vineet Rajgarhia and Dr Christopher Miller are thanked for providing the S. cerevisiae XKS1 gene on pVR103 and the Piromyces XYLA gene on pCM29, respectively. Dr. Aristos Aristidou, and Dr. Vineet Rajgarhia are thanked for frequent discussions.

This work was partially supported by NatureWorks LLC and the United States Department of Energy (contract DE-FC36-021D14349 (formerly DE-F(07-021D14349))

\section{Author details}

${ }^{1}$ VTT Technical Research Centre of Finland, P. O. Box 1000, Espoo Fl-02044 VTT, Finland. ${ }^{2}$ Cargill Biotechnology Research and Development, 15285 Minnetonka Blvd, Minnetonka, MN 55345, USA.

Received: 4 April 2014 Accepted: 15 July 2014

Published: 8 August 2014

\section{References}

1. Wee Y-J, Kim J-N, Ryu H-W: Biotechnological production of lactic acid and its recent applications. Food Technol Biotechnol 2006, 44:163-172.

2. Sauer M, Porro D, Mattanovich D, Branduardi P: Microbial production of organic acids: expanding the markets. Trends Biotechnol 2008, 26:100-108

3. Miller C, Fosmer A, Rush B, McMullin T, Beacom D, Suominen P: Industrial production of lactic acid. Compr Biotechnol 2nd Ed 2011, 3:179-188. http:// dx.doi.org/10.1016/B978-0-08-088504-9.00177-X.
4. Branduardi P, Smeraldi C, Porro D: Metabolically engineered yeasts: "potential" industrial applications. J Mol Microbiol Biotechnol 2008, 15:31-40.

5. Doran-Peterson J, Cook DM, Brandon SK: Microbial conversion of sugars from plant biomass to lactic acid or ethanol. Plant J 2008, 54:582-592.

6. IImén M, Koivuranta K, Ruohonen L, Rajgarhia V, Suominen P, Penttilä M: Production of L-lactic acid by the yeast Candida sonorensis expressing heterologous bacterial and fungal lactate dehydrogenases. Microb Cell Factories 2013, 12:53.

7. Aristidou A, Penttilä M: Metabolic engineering applications to renewable resource utilization. Curr Opin Biotechnol 2000, 11:187-198.

8. Yang CW, Lu Z, Tsao GT: Lactic acid production by pellet-form Rhizopus oryzae in a submerged system. Appl Biochem Biotechnol 1995, 51/52:57-71.

9. Park EY, Anh PN, Okuda N: Bioconversion of waste office paper to L (+)-lactic acid by the filamentous fungus Rhizopus oryzae. Bioresour Technol 2004, 93:77-83.

10. Maas RHW, Bakker RR, Eggink G, Weusthuis RA: Lactic acid production from xylose by the fungus Rhizopus oryzae. Appl Microbiol Biotechnol 2006, 72:861-868.

11. Ilmén $M$, Koivuranta $K$, Ruohonen $L$, Suominen $P$, Penttilä M: Efficient production of L-lactic acid from xylose by Pichia stipitis. Appl Environ Microbiol 2007, 73:117-123.

12. Tamakawa H, Ikushima S, Yoshida S: Efficient production of L-lactic acid from xylose by a recombinant Candida utilis strain. J Biosci Bioeng 2012, 113:73-75.

13. van Maris AJA, Abbott DA, Bellissimi E, van den Brink J, Kuyper M, Luttik MAH, Wisselink HW, Scheffers WA, van Dijken JP, Pronk JT: Alcoholic fermentation of carbon sources in biomass hydrolysates by Saccharomyces cerevisiae: current status. Antonie Van Leeuwenhoek 2006, 90:391-418.

14. Jeffries TW, Jin Y-S: Metabolic engineering for improved fermentation of pentoses by yeasts. Appl Microbiol Biotechnol 2004, 63:495-509.

15. Hahn-Hägerdal B, Karhumaa K, Jeppsson M, Gorwa-Grauslund MF: Metabolic engineering for pentose utilization in Saccharomyces cerevisiae. Adv Biochem Engin/Biotechnol 2007, 108:147-177.

16. Voronovsky A, Ryabova O, Verba O, Ishchuk O, Dmytruk K, Sibirny A: Expression of $x y l A$ genes encoding xylose isomerases from Escherichia coli and Streptomyces coelicolor in the methylotrophic yeast Hansenula polymorpha. FEMS Yeast Res 2005, 5:1055-1062.

17. Brat D, Boles E, Wiedemann B: Functional expression of a bacterial xylose isomerase in Saccharomyces cerevisiae. Appl Environ Microbiol 2009 75:2304-2311

18. Ha S-J, Kim SR, Choi J-H, Park MS, Jin Y-S: Xylitol does not inhibit xylose fermentation by engineered Saccharomyces cerevisiae expressing $x y / A$ as severely as it inhibits xylose isomerase reaction in vitro. Appl Microbiol Biotechnol 2011, 92:77-84.

19. Kuyper M, Harhangi HR, Stave AK, Winkler AA, Jetten MSM, De Laat WTAM, Den Ridder JJJ, Op Den Camp HJM, Van Dijken JP, Pronk JT: High-level functional expression of a fungal xylose isomerase: the key to efficient ethanolic fermentation of xylose by Saccharomyces cerevisiae? FEMS Yeast Res 2003, 4:69-78.

20. Madhavan A, Tamalampudi S, Ushida K, Kanai D, Katahira S, Srivastava A, Fukuda $\mathrm{H}$, Bisaria VS, Kondo A: Xylose isomerase from polycentric fungus Orpinomyces: gene sequencing, cloning, and expression in Saccharomyces cerevisiae for bioconversion of xylose to ethanol. Appl Microbiol Biotechnol 2009, 82:1067-1078.

21. Walfridsson M, Bao X, Anderlund M, Lillius G, Bukow L, Hahn-Hägerdal B: Ethanolic fermentation of xylose with Saccharomyces cerevisiae harbouring the Thermus thermophilus xylA gene, which expresses an active xylose (glucose) isomerase. App/ Environ Microbiol 1996, 62:4648-4651.

22. Chan E-C, Ueng PP, Chen L: D-xylose fermentation to ethanol by Schizosaccharomyces pombe cloned with xylose isomerase gene. Biotech Lett 1986, 8:231-234.

23. Kern M, Haltrich D, Nidetzky B, Kulbe KD: Induction of aldose and xylito reductase activities in Candida tenuis CBS 4435. FEMS Microbiol Lett 1997 149:31-37.

24. Bicho PA, Runnals $L$, Cunningham JD, Lee $H$ : Induction of xylose reductase and xylitol dehydrogenase activities in Pachysolen tannophilus and Pichia stipitis on mixed sugars. Appl Environ Microbiol 1988, 54:50-54.

25. Harhangi HR, Akhmanova AS, Emmens R, van der Drift C, de Laat WTAM, van Dijken JP, Jetten MSM, Pronk JT, Op den Camp HJM: Xylose 
metabolism in the anaerobic fungus Piromyces sp. strain E2 follows the bacterial pathway. Arch Microbiol 2003, 180:134-141.

26. Dmytruk OV, Voronovsky AY, Abbas CA, Dmytruk KV, Ishchuk OP, Sibirny AA: Overexpression of bacterial xylose isomerase and yeast host xylulokinase improves xylose alcoholic fermentation in the thermotolerant yeast Hansenula polymorpha. FEMS Yeast Res 2008, 8:165-173.

27. Sambrook J, Russell DW: Molecular cloning. A laboratory manual. 2nd edition. Cold Spring Harbor, New York, USA: Cold Spring Harbor Laboratory Press; 2001.

28. Ilmén $\mathrm{M}$, Thrane $\mathrm{C}$, Penttilä $\mathrm{M}$ : The glucose repressor gene cre1 of Trichoderma: Isolation and expression of a full length and a truncated mutant form. Mol Gen Genet 1996, 251:451-460.

29. Kötter P, Amore R, Hollenberg CP, Ciriacy M: Isolation and characterization of the Scheffersomyces stipitis xylitol dehydrogenase gene, $X Y L 2$, and construction of a xylose-utilizing Saccharomyces cerevisiae transformant. Curr Genet 1990, 18:493-500.

30. Amore R, Kötter P, Kuster C, Ciriacy M, Hollenberg CP: Cloning and expression in Saccharomyces cerevisiae of the $\mathrm{NAD}(\mathrm{P}) \mathrm{H}$-dependent xylose reductase-encoding gene $(X Y L 1)$ from the xylose-assimilating yeast Pichia stipitis. Gene 1991, 109:89-97.

31. Hallborn J, Walfridsson M, Airaksinen U, Ojamo H, Hahn-Hägerdal B, Penttilä M, Keränen S: Xylitol production by recombinant Saccharomyces cerevisiae. Bio/Technol 1991, 9:1090-1095.

32. Rodriguez-Pena JM, Cid VJ, Arroyo J, Nombela C: The YGR194C (XKS1) gene encodes the xylulokinase from the budding yeast Saccharomyces cerevisiae. FEMS Microbiol Lett 1998, 162:155-160.

33. Gietz RD, Jean AS, Woods RA, Schiestl RH: Improved method for high efficiency transformation of intact yeast cells. Nucleic Acids Res 1992, 20:1425.

34. Lowry OH, Rosebrough NJ, Farr AL, Randall RJ: Protein measurement with the Folin phenol reagent. J Biol Chem 1951, 193:265-275.

35. Toivari MH, Salusjärvi L, Ruohonen L, Penttilä M: Endogenous xylose pathway in Saccharomyces cerevisiae. Appl Environ Microbiol 2004, 70:3681-3686.

36. Richard P, Toivari MH, Penttilä M: Evidence that the gene YLR070c of Saccharomyces cerevisiae encodes a xylitol dehydrogenase. FEBS Lett 1999, 457:135-138.

doi:10.1186/s12934-014-0107-2

Cite this article as: Koivuranta et al:: L-lactic acid production from D-xylose with Candida sonorensis expressing a heterologous lactate dehydrogenase encoding gene. Microbial Cell Factories 2014 13:107.

\section{Submit your next manuscript to BioMed Central and take full advantage of:}

- Convenient online submission

- Thorough peer review

- No space constraints or color figure charges

- Immediate publication on acceptance

- Inclusion in PubMed, CAS, Scopus and Google Scholar

- Research which is freely available for redistribution

Submit your manuscript at www.biomedcentral.com/submit
C Biomed Central 